\title{
EDUCATIONAL INTEREST IN RELATION TO ACADEMIC ACHIEVEMENT OF THE SECONDARY SCHOOL STUDENTS IN MEGHALAYA, INDIA
}

\author{
CAROLINE LYNGDOH TRON \\ Department of Education North-Eastern Hill University (NEHU), \\ Mawkynroh-Umshing, Shillong793022, Meghalaya, India \\ E-mail address: 1troncaroline@gmail.com \\ ORCID: https://orcid.org/0000-0002-5648-3676 \\ BRINDA BAZELEY KHARBIRYMBAI \\ Department of Education North-Eastern Hill University (NEHU), \\ Mawkynroh-Umshing, Shillong793022, Meghalaya, India \\ E-mail address: brindabazeley@gmail.com \\ ORCID: https://orcid.org/0000-0001-6082-1140
}

\begin{abstract}
Aim. The aim of this study is to present the relationship between educational interest and academic achievement of the secondary school students in East Khasi Hills District, Meghalaya, India. The standardised tool used for the study is the Educational Interest Record by Kulshrestha (2016). In order to assess the academic achievement, the final year examination results of students were collected.

Methods. The sample of the study comprised of 300 secondary school students drawn from fifteen secondary schools under Meghalaya Board of School Education. Stratified random sampling was used with equal representation to gender and locale. Analysis was done by using Pearson ' $r$ ' (Product Moment Correlation) and t-test.

Results. The findings of the study revealed a negative relationship between educational and academic achievement. There is a significant difference in the educational interest in terms of gender, but no significant difference was found between locales of the secondary school students.

Conclusions. The assessment of the educational interest may be considered one of the crucial methods used in the education system, as teaching of subjects alone cannot help the students in the educational development. On the other hand, academic achievement is one of the areas in which relatively accurate information can be obtained with relation to individual's ability or capacity. The study has provided information which indicate that students do not have a clear understanding about their own interests and abilities. Hence, guidance and counselling need to be inte-
\end{abstract}


grated into the secondary school curriculum in the state in order to help the students better understand their interests and abilities. Educational guidance and counselling will also enable the students to plan both their higher education and career in the future.

Key words: educational interest, academic achievement, secondary school students

\section{INTRODUCTION}

$\mathrm{I}_{\mathrm{s}}^{\mathrm{n}}$ today's world, a wider choice of educational streams is available for the students than before: each subject has various branches which are not known to all the students. Therefore, students are confronted with the problem of the selection of subjects or courses. There are times that a student realises very late that the path leading him or her towards his or her goal is not visible. The lack of sufficient or up-to-date information is one reason why individuals struggle to take decisions and make unwise choices repeatedly which leads to wastage and stagnation. According to Rashmi Agrawal (2013), with a variety of educational streams as well as occupational opportunities available to the students, it is not always possible for them to match their abilities with the demands of occupations. Secondary school students are at the adolescent stage where new ways of thinking, new associations, and new spheres of concern start developing. Students begin forming certain attitudes towards education and they develop particular likes and dislikes.

Therefore, identifying students' educational interest and relating educational interest with academic achievement will certainly expose out the need of career guidance and counselling of the secondary school stuents.

Educational interest: it is the pattern of interest, the likes and dislikes for certain educational subjects or discipline which has developed in every students; individual's interests or liking and disliking are fairly stable traits of personality; they vary with age and differ among individuals. People often learn to like things they do well, and learn to dislike things they are bad at. The measurement of educational interest can help the students' in choosing their educational goals and enable them to be realistic about their choices and preferences.

Academic achievement: it is the level of students' achievement based on what they have learnt during the current session. Academic achievement is the attainment of short or long-term educational goals or annual examinations. Academic achievement is commonly measured through examinations or continuous assessment.

\section{LITERATURE REVIEW}

The educational interest of the class $\mathrm{X}$ students in relation to their gender and locale was not significant (Narang \& Narang, 2015). The difference in educational interest was found significant in terms of gender alone (Malsawmi, 
Khawlhring, Lalnunfeli, \& Lalchandami, 2019). School counselling programmes help students to develop competencies in academic achievement, personal and social development, as well as career planning (Shaterloo \& Mohammadyari, 2011).

Teachers voluntarily act as informal counsellors guiding students in their choices of subjects and career paths. In addition, students also see their teachers as role models and attach high importance to their advice and guidance related to the subjects and career selection (Khan, Murtaza, \& Shafa, 2012). Young people need counselling and guidance in order to be able to discover abilities, inclinations, and to outline their future. What may also be highlighted is the importance of career counselling conducted in educational institutions and the need to develop national policies to focus on career guidance programmes in high schools and the implementation as a compulsory part of the counselling process (Mihaela \& Cristina, 2015).

Interests are different from abilities but they tend to show some similar patterns. Measures of ability tend to predict measures of performance or efficiency and interests can be used to predict choices. Therefore, the identification and measurement of educational interests in relation to academic achievement was found to be important at the secondary school level.

\section{SIGNIFICANCE OF THE STUDY}

The study on educational interest in relation to academic achievement may be considered necessary to understand students' interests and abilities at the secondary school level. Moreover, based on the review of related literature, the researcher's has not come across any work related to study of the relationship between educational interests and academic achievement. Hence, the researcher decided to conduct a study on educational interests in relation to academic achievement in order to understand the guidance and counselling needs of the secondary school students.

\section{OPERATIONAL DEFINITIONS OF THE TERMS USED}

The operational definitions of the terms used is defined as follows:

- Educational interest: it is the pattern of preferences, likes and dislikes for a given educational area or subject.

- Academic achievement: it refers to the score obtained by an individual student in different subjects in the final examination conducted by Meghalaya Board of School Education (MBOSE).

- Secondary school students: the term secondary school students in this study is the category of education provided in schools for the classes IX and X under Meghalaya Board of School Education (MBOSE). 


\section{DELIMITATION OF THE STUDY:}

The present study was delimited only to the class-X students of the secondary schools in East Khasi Hills District, Meghalaya.

Objectives of the study

- To find out about the relationship between educational interest and academic achievement of the secondary school students.

- To find the difference in educational interest between male and female students.

- To find the difference in educational interest between rural and urban students.

Hypotheses

$\mathrm{H}_{\mathrm{o}}$ 1: There is no significant relationship between educational interest and academic achievement of the secondary school students.

$\mathrm{H}_{\mathrm{o}}$ 2: There is no significant difference in the educational interest between male and female secondary school students.

$\mathrm{H}_{\mathrm{o}}$ 3: There is no significant difference in the educational interest between rural and urban secondary school students.

\section{METHODOLOGY}

\section{Population and sample}

The study consisted of 5986 secondary school students studying in class X, East Khasi Hills District, Meghalaya. From this population, the sample drawn for the present study was 300 secondary school students. Stratified random sampling was used which is selected randomly by giving equal representation for gender and locale.

Tools used

1. Educational Interest Record (EIR) by Kulshrestha (2016)

- The academic achievement of the class X students was collected from the results declared by the Meghalaya Board of School Education (MBOSE)

Analysis and interpretation of data

Objective 1: To find out about the relationship between educational interest and academic achievement of the secondary school students.

$\mathrm{H}_{\mathrm{o}} 1$ : There is no significant relationship between the educational interest and the academic achievement of the secondary school students.

To test the hypothesis, Pearson ' $r$ ' (Product Moment Correlation) was used in the study. Table 1 shows the co-efficient of correlation between educational interest and academic achievement. 
Table 1

Relationship between educational interest and academic achievement

\begin{tabular}{lccccc}
\hline Relationship & $\mathrm{N}$ & $\mathrm{df}$ & $\mathrm{r}$ & ' $^{\prime}$ & Sig.(0.05) \\
\hline EIR-AA & 300 & 298 & $-0.144^{*}$ & 0.138 & Significant \\
\hline Note: ${ }^{*}$ Significant. & & & & & \\
Source: own research.
\end{tabular}

From Table 1, the findings revealed that there was a significant negative relationship between educational interest and academic achievement. Therefore, the null hypothesis was rejected.

Objective 2: To find the difference in educational interest between male and female students.

$\mathrm{H}_{0}$ 2: There is no significant difference in the educational interest between male and female secondary school students.

To test the hypothesis, t-test was used in the study. Table 2 shows the difference in educational interest between male and female students.

Table 2

The difference in the educational interest between male and female students

\begin{tabular}{cccccccccc}
\hline & & & & & & & 't'value $\begin{array}{c}\text { Significant } \\
(0.05)\end{array}$ \\
\hline \multirow{2}{*}{$\begin{array}{c}\text { Education- } \\
\text { al interest }\end{array}$} & Gender & $\mathrm{N}$ & Mean & SD & df & ' $\mathrm{t}^{\prime}$ & & \\
\cline { 2 - 10 } & Male & 150 & 378.34 & 122.99 & & & & \\
\cline { 2 - 10 } & Female & 150 & 347.30 & 136.50 & 289 & $2.06^{*}$ & 1.96 & Significant \\
\hline
\end{tabular}

Source: own research

From Table 2, the findings revealed that there is a significant difference in the educational interest between male and female students at 0.05 level of significance. Hence, null hypothesis is rejected.

Objective 3: To find the difference in educational interest between rural and urban students

$\mathrm{H}_{0}$ 3: There is no significant difference in the educational interest between rural and urban secondary school students.

To test the hypothesis, $\mathrm{t}$-test was used in the study. Table 3 shows the difference in educational interest between rural and urban students.

Table 3

The difference in the educational interest between rural and urban students

\begin{tabular}{|c|c|c|c|c|c|c|c|c|}
\hline \multirow[t]{3}{*}{$\begin{array}{c}\text { Educational } \\
\text { interest }\end{array}$} & Locale & $\mathrm{N}$ & Mean & SD & $\mathrm{df}$ & $' t^{\prime}$ & 't'value & $\begin{array}{c}\text { Significant } \\
\text { level } \\
(0.05)\end{array}$ \\
\hline & Rural & 150 & 372.82 & 134.02 & & & & Not \\
\hline & Urban & 150 & 352.82 & 126.82 & 298 & 1.32 & 1.96 & significant \\
\hline
\end{tabular}

Source: own research. 
Table 3 gives the information that the computed $t$-value is 1.32 and the table $t$-value is 1.96 at 0.05 level of significance. Therefore, it can be stated that there was no significant difference in the educational interest between rural and urban secondary school students with the mean difference in favour of the rural secondary school students. Hence, null hypothesis is accepted.

\section{DISCUSSION}

The findings served as an indicator which clearly signifies the negative correlation between educational interest and academic achievement. This indicates that when one variable increases, the other decreases and vice versa. Understanding the students' interest and their performance is important for the school teachers and teacher-counsellors, as proper guidance and counselling can be given to assist them in making a proper choice of the course/stream for higher education. Since the educational interest and the academic achievement of the secondary school students were found negatively correlated, it was understood that the secondary school students in East Khasi Hills District need guidance and counselling. Academic guidance should be provided by trained/professional counsellors so as to enable the students to understand the importance of matching their educational interests and abilities. When educational interest goes well with academic achievement, it ensures that a student is on the right track. And being on the right track will enable students to develop more interest in the subject with good academic achievement. This will help them to get admission in good colleges and universities as per the subjects of their choice of interests and capabilities. Aalieh Shaterloo \& Ghasem Mohammadyari (2011) reported that in Tehran, a school counselling programme has helped students to develop competencies in academic achievement, personal and social development, and career planning. Therefore, the findings are a signal to the state policy makers and stakeholders, that there is a need for the integration of guidance and counselling into the secondary school curriculum in Meghalaya. The findings were not in tune with Vipul Narang \& Susheela Narang (2015) in terms of gender, but they were consistent in terms of locale. Whereas they were in tune with the findings by $\mathrm{H}$. Malsawmil, Malsawmi Khawlhring, Donna Lalnunfeli and Sian Lalchandami (2019) in Mizoram, the similarity in the findings in the two states, Meghalaya and Mizoram, needs further research to bring out the underlying facts which lead to significant differences in the educational interest related to gender in the two states, the two sisters among the seven sisters in North East India. The integration of guidance and counselling in secondary schools will help the students discover their own abilities and interests and it will enable them to outline their future plan in education. The need was felt for all stakeholders and in particular the state policy makers to focus on the integration of guidance and counselling, as well as career guidance and counselling in all secondary schools throughout the state as recommended by the National Curriculum Framework (2005). It was also necessary to recruit professional counsellors or teacher-counsellors so that 
they could handle it with proficiency and effectiveness. The findings reported by Nita Andreea Mihaela and Ilie Goga Cristina (2015) in Romania, SouthWest Oltenia, and Wallachia South support the needs of career guidance and counselling in secondary schools.

\section{IMPLICATIONS AND RECOMMENDATIONS}

The findings of the present study have implications for the policy makers, teacher- counsellors, parents and other stakeholders in the field of education. Understanding the fact that students' educational interest was not in the same direction with their abilities or capacities, therefore the integration of career guidance and counselling is the need of the hour at the secondary schools. According to Ndirangu Prisca Njeri (2007), guidance and counselling programmes have a positive impact on the academic performance of students. It is also mandatory to all stakeholders to understand that information on individual students' educational interests need to be collected prior to rendering of educational guidance. Moreover, it must be understood that rendering educational guidance is not everybody's job; it requires the services of trained guidance personnel, teacher-counsellors, career masters, psychologists, and counsellors. Based on the findings, a few recommendations are given below:

1. Policy makers need to bring in innovations in the education system with the introduction of guidance and counselling in general and career guidance. Counselling in particular should be introduced in the school curriculum at the secondary school level.

2. State government needs to provide in-service training in the area of guidance and counselling to all subject teachers.

3. State government needs to recruit professional counsellors at all school levels.

4. State government should give directions to all subject teachers in order to integrate educational and academic guidance in the teaching of school subjects so as to help the students in their educational growth and development according to their own capacities and abilities.

\section{CONCLUSIONS}

Multiplicity of courses and diversity in subject combinations have complicated the students' decision-making skills in the selection of subjects or courses. The wrong choice of subject may have a negative influence on their career and future. Many students fail repeatedly which leads to the wastage of human resources at the state and national level. Such wastage and stagnation can only be checked through a suitable programme of career guidance and counselling. Career guidance and counselling do not only assist the students in making educational choices but it also guide them to achieve maximum educational growth and development according to their own interests and abilities. The 
teacher-counsellor model is one way of fulfilling both guidance and teaching activities which is complementary for the all round development of the students. The teacher-counsellors can also focus on career counselling which will help the students to make realistic educational choices, establish life goals, and resolve educational and career-related problems.

\section{REFERENCES}

[1] Agarwal, R. (2013). Educational vocational guidance and counselling: Principles, techniques and programmes. India. Shipra Publications.

[2] Khan, H, Murtaza, F., \& Shafa, D. M. (2012). Role of teachers in providing educational and career counselling to the secondary school students in Gilgit-Baltistan of Pakistan. International Journal of Academic Research in Progressive Education and Development, 1(2) 85-101.

[3] Kulshrestha, S. P. (2016). Manual for educational interest record. National Psychological Corporation (Estd 1971). www.npcindia.com

[4] Malsawmi, H., Khawlhring, M., Lalnunfeli, D., \& Lalchandami S. (2019). Educational interests of secondary school students of Champhai District, Mizoram. e-Journal, 4(2) 19-22.

[5] Mihaela A. N., \& Cristina, G. A. (2015). A research on the educational counseling and career guidance in Romania. European Scientific Journal, 2 28-33.

[6] Narang, V., \& Narang, S. (2015). Study of educational interests of xth class students of Tehsil Abohar, International Journal of Education and Information Studies, 5(1), 51-57.

[7] National Curriculum Framework (2005). Schemes of study and assessment: Secondary school. National Council of Educational Research and Training (NCERT). Retrieved May 15, 2021, from https://ncert.nic.in/pdf/nc-framework/nf2005-english.pdf

[8] Njeri, P. N. (2007). Influence of guidance and counselling programme of selected public secondary school students. Retrieved March 20, 2018, from http:/ /ir-library.egerton.ac.ke/jspui/b

[9] Shaterloo, A., \& Mohammadyari, G. (2011). Students counseling and academic achievement. Procedia - Social and Behavioral Sciences, 30, 625-628. doi: 10.1016/j.sbs pro.2011.10.121. 